\title{
OPTIMIZATION OF POLYSACCHARIDES PRODUCTION BY BACTERIA ISOLATED FROM SOIL
}

\author{
Silvia Messias Bueno; Crispin Humberto Garcia-Cruz* \\ Departamento de Engenharia e Tecnologia de Alimentos, Instituto de Biociências, Letras e Ciências Exatas, Universidade \\ Estadual Paulista, São José do Rio Preto, SP, Brasil
}

Submitted: May 29, 2004; Returned to authors for corrections: March 22, 2005; Approved: March 26, 2006

\begin{abstract}
Six polysaccharide-producing bacteria, isolated from soil samples and identified as Pseudomonas and Arthrobacter (Strains 3B, 4B, 7B, 21B, 18E and 21D), were tested for the yield of polysaccharides produced during growth in two culture media: one containing glucose and the other sucrose $(1,2,3,4$ and 5\%). The yield was quantified measuring the viscosity of the broth, using the Poiscuille equation. The effect of temperature and $\mathrm{pH}$ of the culture media was investigated. The largest polysaccharide yield was obtained when the concentration of the carbon source was lower than $2 \%$. Glucose and sucrose stimulated the polysaccharide production in a similar way. When the initial $\mathrm{pH}$ of the fermentation broth was increased from 5.0 up to 7.0, there was an increase in polysaccharide production. However, higher values $(\mathrm{pH}=8.0)$ caused a decrease in polysaccharide production. With regard to temperature, $30^{\circ} \mathrm{C}$ was shown to be optimum, since higher or lower temperatures had a negative effect on saccharide production.
\end{abstract}

Key words: bacteria, soil, polysaccharide production, viscosity

\section{INTRODUCTION}

In recent years there has been a continuous search for new water-soluble polysaccharides, particularly those produced by microorganisms. The environment contains a great variety of microorganisms, and in consequence it is expected that new productive microorganisms can be isolated. These biopolymers have been attracting interest due to their great application potential in food, cosmetic, pharmaceutical and oil industries, where they are used as thickening, stabilizing and emulsifying agents. Therefore, the identification of new production sources for these materials is of great interest, specially when such biopolymers possess good rheological properties (4).

Microbial exopolysaccharides are traditionally good substitutes of gums from plants and marine algae. Their physical and chemical characteristics show little variability and they are not vulnerable to variations in climatic, cultivation, production or pollution conditions (6). Besides, gums of microbial origin are susceptible to natural biodegradation, promoting little damage to the environment and diminishing pollution. For this reason, some bacterial polysaccharides are produced on an industrial scale and used as raw material for processed foods, in medicine and in industrial preparations (3).

The present work searched for new polysaccharideproducing microorganisms in soil. After isolation and identification of these microorganisms the optimal production conditions were determined. The effect of $\mathrm{pH}$ and temperature on growth was also investigated.

\section{MATERIALS AND METHODS}

\section{Organism and growth conditions}

The bacteria were isolated from soil samples and identified to genus level by means of biochemical tests. The bacteria were

*Corresponding Author. Mailing address: Universidade Estadual Paulista, IBILCE, Departamento de Engenharia e Tecnologia de Alimentos. 15054-000, São José do Rio Preto, SP, Brasil. Tel.: (+5517) 221-2260, Fax: (+5517) 221-2299. E-mail: crispin@ibilce.unesp.br 
inoculated in slants of PCA (Plate Count Agar), incubated for $24 \mathrm{~h}$ at $30^{\circ} \mathrm{C}$, and then suspended in $10.0 \mathrm{~mL}$ sterile distilled water. The cell suspension was transferred to $250 \mathrm{~mL}$ Erlenmeyer flasks containing $50 \mathrm{~mL}$ of the fermentation medium suggested by Souw and Demain (7), and incubated in a shaker at $30^{\circ} \mathrm{C}$ and $210 \mathrm{rpm}$ for $96 \mathrm{~h}$. The basal medium for fermentation consisted of $(\mathrm{g} / \mathrm{L}): \mathrm{KH}_{2} \mathrm{PO}_{4}, 5.0 ; \mathrm{MgSO}_{4} .7 \mathrm{H}_{2} \mathrm{O}, 0.2 ;\left(\mathrm{NH}_{4}\right)_{2} \mathrm{SO}_{4}, 2.0$; Citric acid, $2.0 ; \mathrm{H}_{3} \mathrm{BO}_{3}, 0.006 ; \mathrm{ZnO}, 0.006 ; \mathrm{FeCl}_{3} .6 \mathrm{H}_{2} \mathrm{O}, 0.0024 ; \mathrm{CaCO}_{3}$, 0.02 and $\mathrm{HCl}, 0.15$. The $\mathrm{pH}$ was adjusted to 7.0 with $\mathrm{NaOH}$ or $\mathrm{HCl}$ (before sterilization). The polysaccharide production medium was obtained by the addition of sterilized solutions of glucose or sucrose, in concentrations of $1.0 ; 2.0 ; 3.0 ; 4.0$ and $5.0 \%$. The different formulations of the production medium were inoculated with centrifuged cells (8000rpm for $30 \mathrm{~min}$ ), previously incubated in Souw and Demain medium (7), to achieve a final optical density of 0.05 at $650 \mathrm{~nm}$. The flasks were incubated at $30^{\circ} \mathrm{C}$, for $72 \mathrm{~h}$ at $210 \mathrm{rpm}$. The polysaccharides produced were separated from the fermentation broth by precipitation with three volumes of ethanol, and removal of the cells by centrifugation at $8000 \mathrm{rpm}$ for $30 \mathrm{~min}$. The solution was concentrated by vacuum evaporation and the gum obtained was vacuum-dried in a oven at $45^{\circ} \mathrm{C}$ until constant weight. The yield was calculated as grams of polysaccharide produced per 100 grams carbon source consumed. Growth was determined measuring the dry weight of the centrifuged cells, placed in Petri plates and vacuum-dried in a oven at $45^{\circ} \mathrm{C}$ to constant weight. In order to evaluate the influence of $\mathrm{pH}$, the $\mathrm{pH}$ of production medium was adjusted 5, 6, 7 and 8 , using $\mathrm{NaOH} 1 \mathrm{~N}$. The effect of the temperature was observed at 25,30 and $35^{\circ} \mathrm{C}$. The cellular growth kinetics was determined using a spectrophotometric method at $650 \mathrm{~nm}$.

\section{Determination of the fermentation broth viscosity}

The volumetric flow was calculated measuring the time that $4 \mathrm{~mL}$ of the fermentation broth took to flow through a glass capillary tube $(0.8 \mathrm{~cm}$ diameter and $25 \mathrm{~cm}$ length $)$ at $25^{\circ} \mathrm{C}$ (equation 1). The viscosity was calculated by means of the Poiseuille equation (equation 2) (9).

$$
\begin{array}{ll}
\forall=\frac{\mathrm{v}}{\mathrm{t}} \quad \text { (equation 1) } & \forall=\text { volumetric flow }\left(\mathrm{cm}^{3} / \mathrm{s}\right) \\
& \mathrm{v}=\operatorname{volume}\left(\mathrm{cm}^{3}\right) \\
& \mathrm{t}=\operatorname{time}(\mathrm{s}) \\
& \\
& \mathrm{L}=\frac{\pi \Delta \mathrm{P} \mathrm{r}^{4}}{8 \mathrm{~L} \mu} \text { (equationgth }(\mathrm{cm}) \\
& \mathrm{r}=\operatorname{radius}(\mathrm{cm}) \\
& \mathrm{P}=\text { pressure }(\mathrm{Pa}) \\
& \forall=\operatorname{volumetric} \text { flow }\left(\mathrm{cm}^{3} / \mathrm{s}\right) \\
& \mu=\operatorname{specific} \text { viscosity }(\mathrm{Pa} . \mathrm{s})
\end{array}
$$

\section{Statistical design}

Results were compared by means of Tukey's test, at a level of significance of 1\%, using the Estat program, version 2.0.

\section{RESULTS AND DISCUSSION}

Several polysaccharide producing bacteria were isolated from soil of Northwest São Paulo Ecological Station, in the State of São Paulo, Brazil. Six strains (3B, 4B, 7B, 21B, 18E and 21D), belonging to Pseudomonas and Arthrobacter genera, were selected for this study. The steps for their identification are shown in Fig. 1.

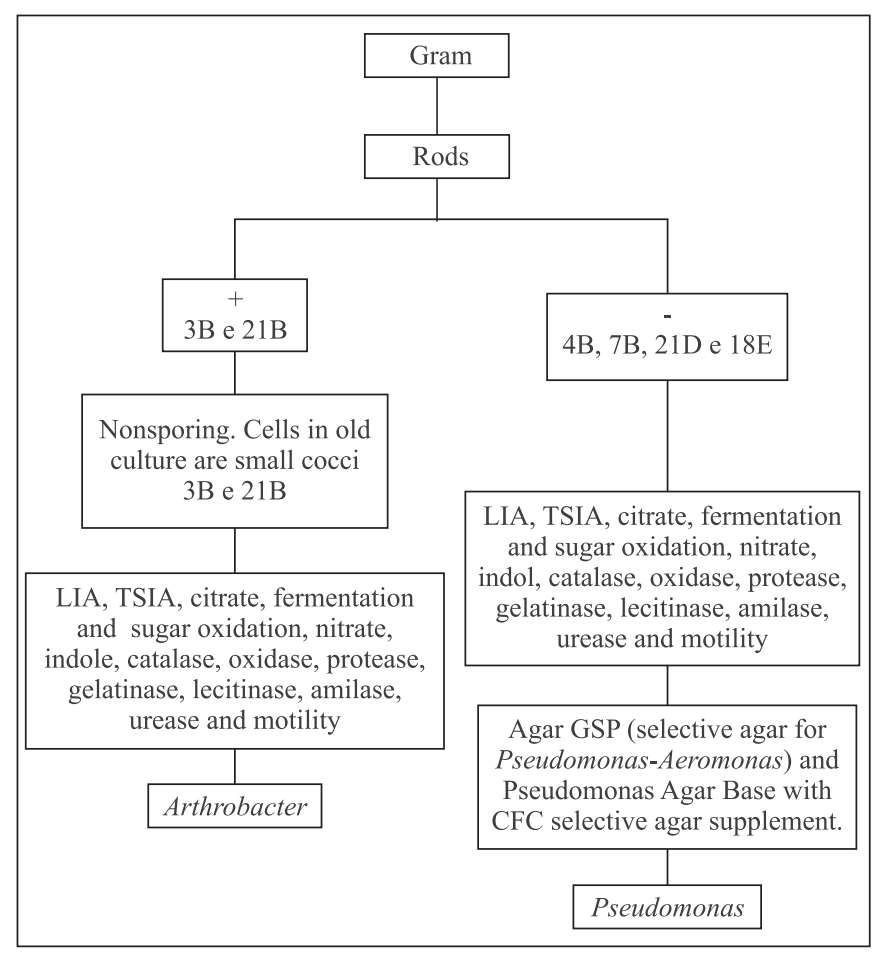

Figure 1. Steps of identification of bacteria isolated from soil.

The biochemical tests employed were LIA (Lysin-Iron-Agar), TSIA (Triple-Sugar-Iron-Agar), citrate, fermentation and oxidation of carbon sources (sucrose, lactose, glucose, maltose and manitol), nitrate, indole, catalase, protease, lecithinase, amylase, gelatinase, oxidase, urease and motility. The specific tests for Pseudomonas were growth in Agar GSP (Merck) and Pseudomonas Agar Base in the presence of CFC selective agar supplement (Oxoid).

As shown in Fig. 2, broths containing strains 3B, 4B, 7B and $18 \mathrm{E}$ presented maximum viscosity after $72 \mathrm{~h}$ cultivation. Strains $21 \mathrm{~B}$ and $18 \mathrm{E}$ achieved maximum viscosity after $48 \mathrm{~h}$. The high viscosity presented by strain $4 \mathrm{~B}$ remained practically constant up to $72 \mathrm{~h}$. In general, after $72 \mathrm{~h}$ incubation the viscosity decreased for all studied bacteria (Fig. 2).

The growth kinetics (Fig. 3), carried out to determine the relationship between cellular growth and polysaccharide 


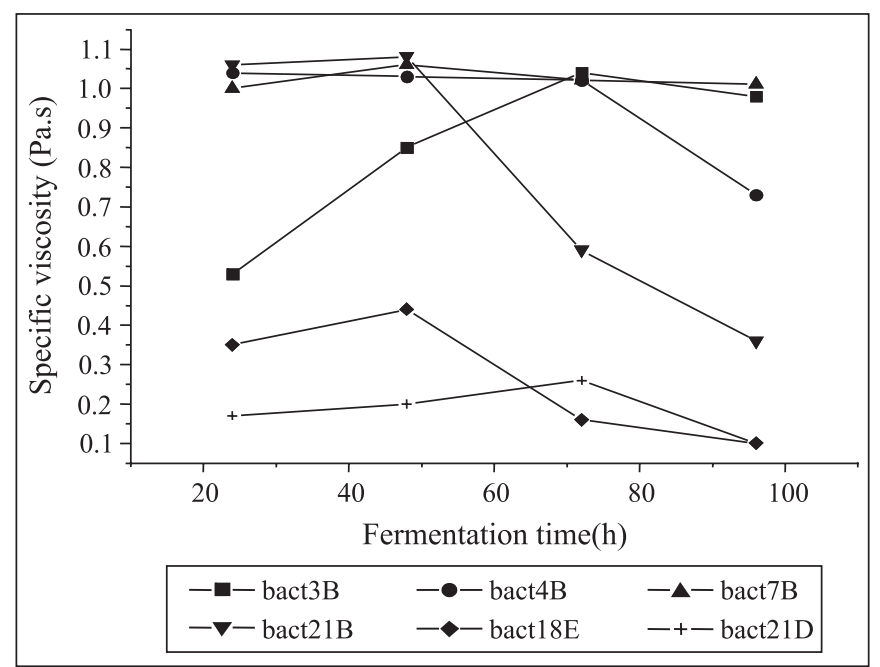

Figure 2. Viscosity of the culture media during growth of polysaccharide-producing bacteria, up to $96 \mathrm{~h}$ at $30^{\circ} \mathrm{C}$ and $210 \mathrm{rpm}$.

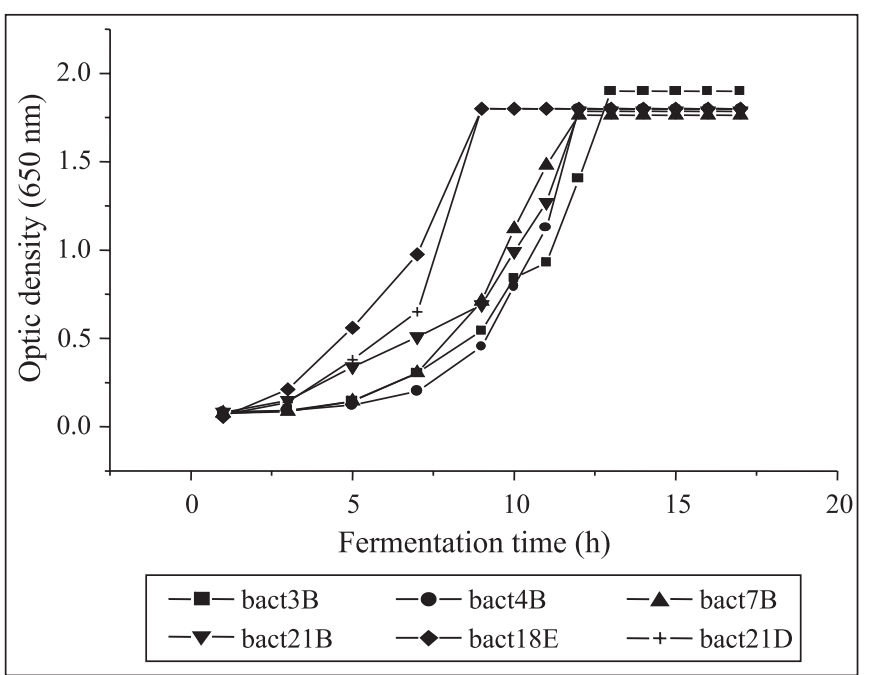

Figure 3. Growth of polysaccharide-producing bacteria determined by spectrophotometric readings (Cultivation conditions: $30^{\circ} \mathrm{C}$ and $210 \mathrm{rpm}$ ).

production, shows that strains $3 \mathrm{~B}, 4 \mathrm{~B}, 7 \mathrm{~B}$ and $21 \mathrm{~B}$ achieved maximum biomass concentration in $12 \mathrm{~h}$, while strains $18 \mathrm{E}$ and 21D reached the stationary growth phase in 8-9 h. Previous studies with xanthan gum have shown that the production of the gum occurs after the logarithmic growth phase, i.e. in the stationary phase (5).

Many bacterial polysaccharides are produced in batch fermentation processes using different sugars as carbon sources $(1,8)$, but glucose has been used as the traditional carbon source $(2,5,6,10)$. The productivity can be affected by culture conditions, such as composition of the culture medium, temperature, $\mathrm{pH}$ and aeration efficiency (3).

In this work we also studied sucrose, because it is cheaper and more abundant in the national market. The results are shown in Figs. 4, 5 and 6. In Fig. 4, it can be observed that polysaccharide yield decreases when the concentration of carbon sources increases. This behavior has been observed by several researchers $(5,7,10)$ during polysaccharide production using the most varied types of bacteria.

The glucose concentrations that resulted in the largest polysaccharide varied between $1 \%$ and $2 \%$. For strains $3 \mathrm{~B}, 18 \mathrm{E}$ and 21D, the larger yields were achieved at $1 \%$ glucose, and decreased drastically beyond this value.

The sucrose concentration that led to the largest yield was $2 \%$, except for strains $21 \mathrm{~B}$ and $18 \mathrm{E}$, which produced the largest yield at $1 \%$. The strain $18 \mathrm{E}$ presented the same behavior for the two carbon sources (Fig. 4). The variance analysis by Tukey's test indicated significant differences at a level of $1 \%$ for the carbon source concentrations studied.

With regards to the carbon source tested, the strains provided similar results for glucose and sucrose. The same behavior was observed by Souw and Demain (7) during the production of xanthan gum by Xanthomonas campestris. Therefore, for polysaccharide production, glucose can be substituted by sucrose, presenting the advantage of being cheaper.

Table 1 shows the effect of glucose and sucrose concentrations on cellular growth. It can be seen that results varied according to the strain and that growth was affected by the type and concentration of the carbon source. In general, as glucose or sucrose concentration increased, growth decreased.

Table 1. Effect of concentration of glucose and sucrose on growth of polysaccharide producing bacteria.

\begin{tabular}{|c|c|c|c|c|c|c|}
\hline Strain & 3B & 4B & $7 \mathrm{~B}$ & 21B & 21D & $18 \mathrm{E}$ \\
\hline$\%$ & \multicolumn{6}{|c|}{$\begin{array}{l}\text { Dry Cellular Weight } \\
\text { (g) }\end{array}$} \\
\hline \multicolumn{7}{|l|}{ Glucose } \\
\hline 1.0 & 0.7658 & 0.5275 & 0.5015 & 0.5935 & 0.6342 & 0.6234 \\
\hline 2.0 & 0.7439 & 0.5291 & 0.4919 & 0.5853 & 0.6221 & 0.6220 \\
\hline 3.0 & 0.6850 & 0.5255 & 0.4912 & 0.5681 & 0.6204 & 0.6215 \\
\hline 4.0 & 0.6758 & 0.5284 & 0.4900 & 0.5666 & 0.6015 & 0.6210 \\
\hline 5.0 & 0.6248 & 0.5192 & 0.4860 & 0.5565 & 0.6045 & 0.6205 \\
\hline \multicolumn{7}{|l|}{ Sucrose } \\
\hline 1.0 & 0.6072 & 0.5331 & 0.4956 & 0.5893 & 0.5362 & 0.6435 \\
\hline 2.0 & 0.5284 & 0.5321 & 0.4990 & 0.5653 & 0.5284 & 0.6390 \\
\hline 3.0 & 0.5261 & 0.5364 & 0.4982 & 0.5546 & 0.5261 & 0.6394 \\
\hline 4.0 & 0.5204 & 0.5320 & 0.4972 & 0.5607 & 0.5104 & 0.6253 \\
\hline 5.0 & 0.5255 & 0.5307 & 0.4575 & 0.5660 & 0.5155 & 0.6224 \\
\hline
\end{tabular}




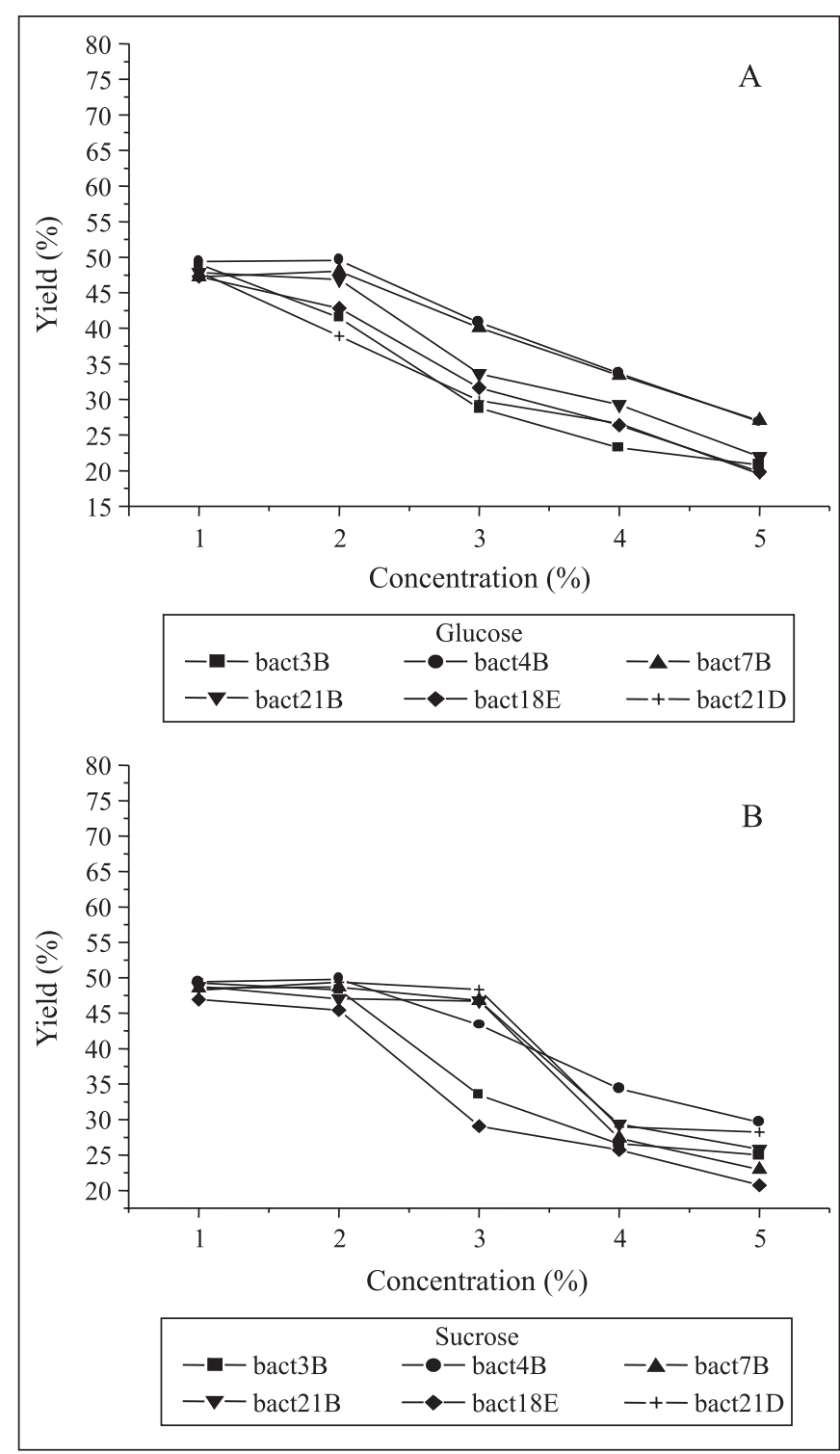

Figure 4. Polysaccharide yields of bacteria isolated from soil, as a function of the carbon source concentration $(A=$ Glucose, $\mathrm{B}=$ Sucrose).

To study the effect of $\mathrm{pH}$ and temperature on polysaccharide production, glucose and sucrose concentration were set at values which had provided the best production, i.e., $1 \%$ of glucose for 3B, 18E and 21D, 2\% glucose for $4 \mathrm{~B}, 7 \mathrm{~B}$ and $21 \mathrm{~B}, 1 \%$ sucrose for $21 \mathrm{~B}$ and $18 \mathrm{E}$ and $2 \%$ sucrose for $3 \mathrm{~B}, 4 \mathrm{~B}, 7 \mathrm{~B}$ and $21 \mathrm{D}$ (Fig. 4).

Fig. 5 and Table 2 show increase in the effect of $\mathrm{pH}$ on polysaccharide production and cellular growth respectively. It can be observed that increase of $\mathrm{pH}$ of the fermentation broth from 5.0 to 7.0 resulted in increase of polysaccharide yields.

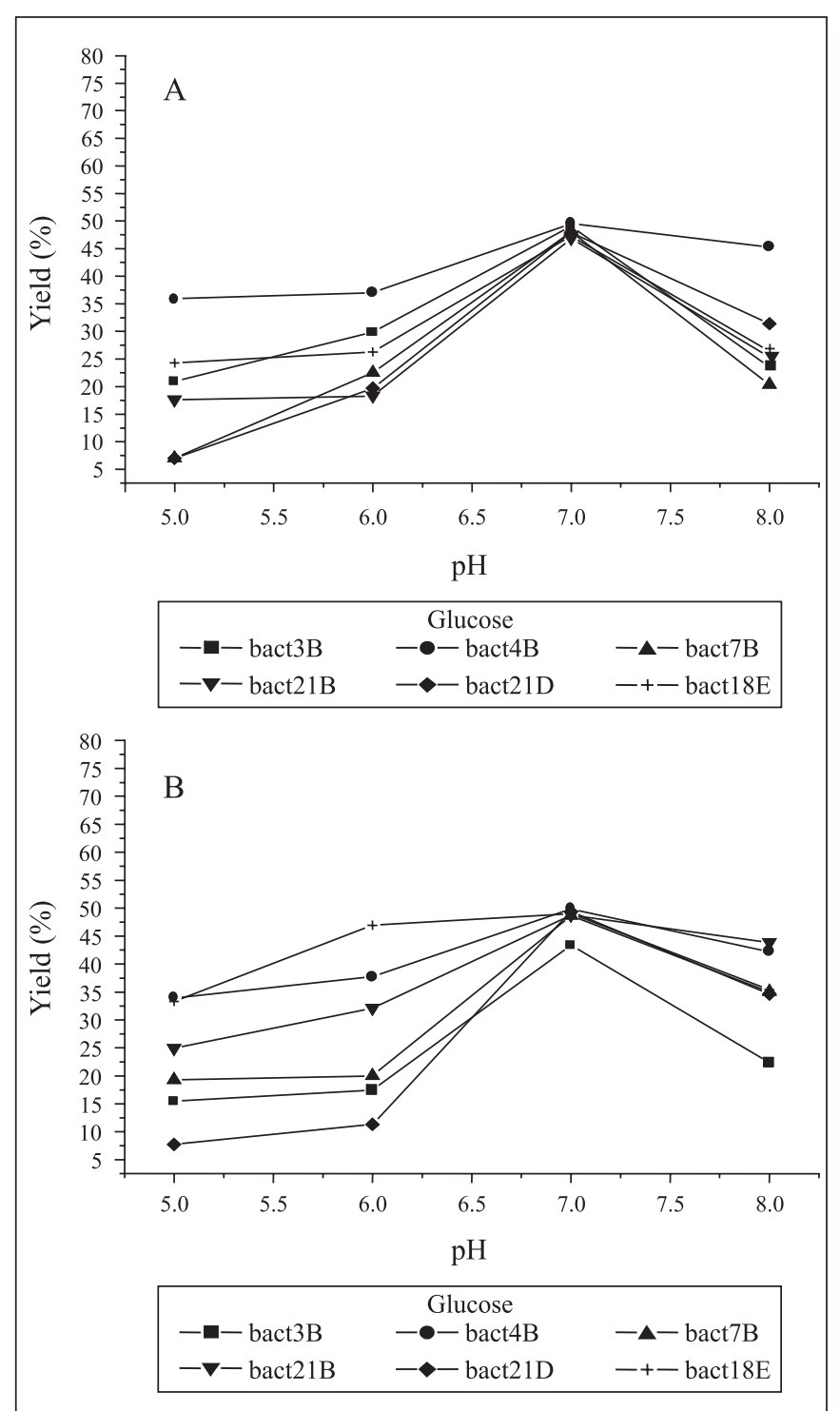

Figure 5. Influence of $\mathrm{pH}$ of the fermentation broth on polysaccharide yield.

However, at $\mathrm{pH} 8.0$ the yield decreased. The variance analysis by Tukey's test presented significant differences at a level of $1 \%$ for the $\mathrm{pH}$ values tested.

Fig. 6 and Table 3 show the effects of incubation temperatures on polysaccharide production and the cellular growth, respectively. It may be observed that the optimal temperature was $30^{\circ} \mathrm{C}$. Lower or higher temperatures had a negative effect on the production of the polysaccharide, indicating that temperature of the culture medium is an important factor to be controlled during production of polysaccharides. The variance analysis by Tukey's test presented significantly differences at a level of $1 \%$ for the temperatures tested. 
Table 2. Effect of $\mathrm{pH}$ of the culture medium containing glucose or sucrose on growth of polysaccharide producing bacteria.

\begin{tabular}{ccccccc}
\hline Strain & $3 \mathrm{~B}$ & $4 \mathrm{~B}$ & $7 \mathrm{~B}$ & $21 \mathrm{~B}$ & $21 \mathrm{D}$ & $18 \mathrm{E}$ \\
\hline $\mathrm{pH}$ & \multicolumn{6}{c}{$\begin{array}{c}\text { Dry Cellular Weight } \\
(\mathrm{g})\end{array}$} \\
\hline Glucose & $1.0 \%$ & $2.0 \%$ & $2.0 \%$ & $2.0 \%$ & $1.0 \%$ & $1.0 \%$ \\
\hline 5 & 0.0299 & 0.0516 & 0.0348 & 0.0212 & 0.1021 & 0.1049 \\
6 & 0.1599 & 0.1723 & 0.0443 & 0.0373 & 0.1189 & 0.1334 \\
7 & 0.6658 & 0.6291 & 0.4919 & 0.5653 & 0.5842 & 0.6234 \\
8 & 0.1825 & 0.2217 & 0.0834 & 0.0566 & 0.1178 & 0.1434 \\
\hline Sucrose & $2.0 \%$ & $2.0 \%$ & $2,0 \%$ & $1.0 \%$ & $2.0 \%$ & $1.0 \%$ \\
\hline 5 & 0.0246 & 0.0514 & 0.0308 & 0.0131 & 0.0405 & 0.0839 \\
6 & 0.1511 & 0.1470 & 0.0982 & 0.0315 & 0.0656 & 0.0992 \\
7 & 0.6658 & 0.6321 & 0.4890 & 0.5393 & 0.5284 & 0.6235 \\
8 & 0.3901 & 0.1585 & 0.1135 & 0.0812 & 0.0340 & 0.1526 \\
\hline
\end{tabular}

Table 3. Effect of temperature on growth of polysaccharide producing bacteria.

\begin{tabular}{ccccccc}
\hline Strain & $3 \mathrm{~B}$ & $4 \mathrm{~B}$ & $7 \mathrm{~B}$ & $21 \mathrm{~B}$ & $21 \mathrm{D}$ & $18 \mathrm{E}$ \\
\hline $\begin{array}{c}\text { Temperature } \\
{ }^{\circ} \mathrm{C}\end{array}$ & \multicolumn{6}{c}{$\begin{array}{c}\text { Dry Cellular Weight } \\
(\mathrm{g})\end{array}$} \\
\hline Glucose & $1.0 \%$ & $2.0 \%$ & $2.0 \%$ & $2.0 \%$ & $1.0 \%$ & $1.0 \%$ \\
\hline 25 & 0.2360 & 0.5185 & 0.0213 & 0.0358 & 0.1286 & 0.1820 \\
30 & 0.6058 & 0.6291 & 0.4819 & 0.5653 & 0.5842 & 0.6234 \\
35 & 0.1080 & 0.5010 & 0.048 & 0.0238 & 0.1145 & 0.1497 \\
\hline Sucrose & $2.0 \%$ & $2.0 \%$ & $2.0 \%$ & $1.0 \%$ & $2.0 \%$ & $1.0 \%$ \\
\hline 25 & 0.2757 & 0.5205 & 0.0372 & 0.0474 & 0.0605 & 0.1593 \\
30 & 0.6072 & 0.6321 & 0.4890 & 0.5393 & 0.5284 & 0.6235 \\
35 & 0.1185 & 0.5183 & 0.0450 & 0.0283 & 0.0345 & 0.1731 \\
\hline
\end{tabular}

After optimization of production conditions, the $\mathrm{pH}$ during the fermentation was monitored. The final $\mathrm{pH}$ values are present in Table 4. These results suggest that the product is probably an acidic polysaccharide or that some organic acids are formed during the synthesis of the polysaccharide by strains $3 \mathrm{~B}, 4 \mathrm{~B}$, $7 \mathrm{~B}$ and $21 \mathrm{~B}$, whereas strains $21 \mathrm{D}$ and $18 \mathrm{E}$ probably produce neutral polysaccharides.

\section{ACKNOWLEDGEMENTS}

This research was supported by FAPESP (Fundação de Amparo à Pesquisa do Estado de São Paulo, SP, Brazil).

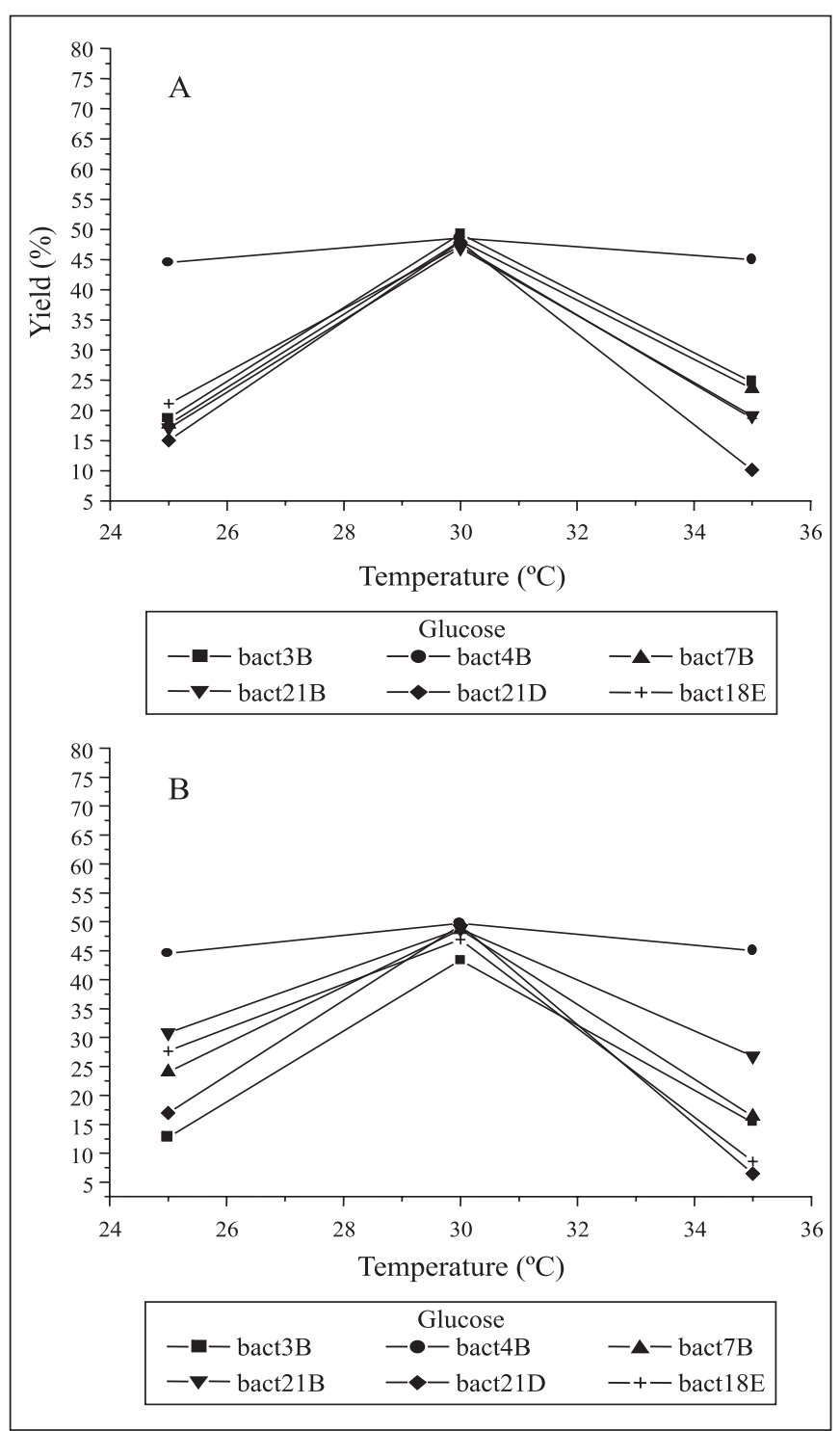

Figure 6. Influence of temperature of incubation on polysaccharide yield.

Table 4. Final $\mathrm{pH}$ of the fermentation broth containing glucose or sucrose.

\begin{tabular}{ccc}
\hline \multicolumn{2}{c}{ Final $\mathrm{pH}$} \\
\hline Strain & Glucose & Sucrose \\
\hline 3B & 5.45 & 4.75 \\
4B & 5.47 & 5.52 \\
7B & 5.48 & 5.46 \\
21B & 6.90 & 5.00 \\
21D & 7.08 & 7.53 \\
18E & 7.05 & 6.88 \\
\hline
\end{tabular}




\section{RESUMO}

\section{Otimização das condições de produção de polissacarídeos por bactérias isoladas do solo}

Seis bactérias produtoras de polissacarídeos isoladas de amostras do solo (3B, 4B, 7B, 21B, 18E e 21D) pertencentes aos gêneros Pseudomonas e Arthrobacter, foram testadas quanto ao rendimento da produção de polissacarídeos em dois caldos de cultura: um com glicose e outro com sacarose, nas concentrações de 1, 2, 3, 4 e 5\%. O rendimento foi calculado medindo-se a viscosidade dos caldos, através da equação de Poiseuille. Também foi verificado o efeito da temperatura de incubação $\left(25,30\right.$ e $\left.35^{\circ} \mathrm{C}\right)$ e o do $\mathrm{pH}(5,6,7$ e 8$)$ dos meios de cultura. Os resultados obtidos mostraram que concentrações da fonte de carbono até $2 \%$ apresentaram os maiores rendimentos do polissacarídeo. Glicose e sacarose estimularam a produção de polissacarídeos de forma similar. Quando o $\mathrm{pH}$ inicial do caldo de fermentação aumentou de 5,0 para 7,0 ocorreu um aumento da produção do polissacarídeo. Entretanto, valores mais altos $(\mathrm{pH}=8,0)$ causaram uma diminuição na formação do produto. Com relação à temperatura, $30^{\circ} \mathrm{C}$ foi considerada ótima, pois temperaturas maiores ou menores do que esta exerceram um efeito negativo na produção do polissacarídeo.

Palavras-chave: bactérias, solo, produção de polissacarídeos, viscosidade

\section{REFERENCES}

1. Bueno, S.M.; Garcia-Cruz, C.H. The Influence of Fermentation Time and the Presence of Salts in the Rheology of the Fermentation Broth of a Polysaccharide-Producing Bacteria Free of Soil. J. Food Eng., 50, 41-46, 2001

2. Kang, K.S.; Veeder, G.T.; Mirrasoul, P.J.; Kaneko, T.; Cottrell, W. Agar-Like Polysaccharide Produced by a Pseudomonas Species: Production and Basic Properties. Appl. Environ. Microbiol., 43(5), 1086-1091, 1982.

3. Kawai, H.; Isobe, Y.; Koribe, M.; Tokuda, J.; Tokuno, I.; Endo, K.; Kawai, F. Production of a Novel Extracellular Polysacharide by a Bacillus Strain Isolated from Soil. Biosci. Biotechnol. Biochem., 56(6), 853-857, 1992.

4. Philippis, R.; Sili, C; Tassinato, G.; Vincenzini, M.; Materassi, R. Effects of Growth Conditions on Exopolysaccharide Production by Cynospira capsulata. Biores. Technol., 38, 101-104, 1991.

5. Rajeshwari, K.V.; Prakash, G.; Ghosh, P. Improved Process for Xanthan Production Using Modified Media and Intermittent Feeding Strategy. Lett. Appl. Microbiol., 21, 173-175, 1995.

6. Roseiro, J.C.; Esgalhado, M.E.; Amaral-Collaço M.T.; Emery A.N. Medium Development for Xanthan Production. Process Biochem., 27, 167-175, 1992.

7. Souw, P.; Demain, A.L. Nutritional Studies on Xanthan Production by Xanthomonas campestris NRRL-B-1459. Appl. Environ. Microbiol., 37, 1186-1196, 1979.

8. Vandamme, E.J.; Bruggeman, G.; Baets, S.; Vanhooren, P.T. Useful Polymers of Microbial Origin. Agro Food Ind. Hi- Tech., 1996, pp. 21-25.

9. Van Holde, K.E. Bioquímica Física. Viscosidade. Ed. Edgard Blücher, 1975, pp. 108-121.

10. Williams, A.G.; Wimpenny, J.W.T. Exopolysaccharide Production by Pseudomonas NCIB 11264 Grown in Batch Culture. J. Gen. Microbiol., 102, 13-21, 1977. 